\title{
Prehospital Trauma Care Registry Problems in South Brazil
}

\author{
${ }^{1}$ Phillipe Abreu-Reis, ${ }^{2}$ Flavio Saavedra Tomasich, ${ }^{3}$ Adonis Nasr, ${ }^{4}$ Iwan Collaco
}

\begin{abstract}
Background: Trauma registry remains a great problem to most countries that are implementing trauma systems. Nondigital data assessment and storage may lead to information deterioration along the process. In order to verify the missing registry in prehospital trauma rescuers' form, we ran this study.

Study design: A prospective observational noncontrolled study with 288 random trauma cases brought to a Level 1 Trauma Center in Curitiba, between May 28th and June 10th 2006. We analyzed data registered in the prehospital rescue team form. The including criteria were all patients delivered to the trauma center by ambulances. The excluding criteria were patients not transported by ambulances and those without the proper form filled out. Statistical analysis was performed using the Chi-square for discrete, and the student's t-test for continuous variables.
\end{abstract}

Results: Two hundred and eighty-eight trauma cases were observed. Twelve patients were excluded. Of the 276 patients who met the including criteria, $75 \%$ were men with a mean age of 27 -year-old. In only $8.34 \%$ of times patients were brought by doctors, while in $91.66 \%$ by paramedics. $63.4 \%$ of patients were traffic injuries victims, followed by $12.31 \%$ falls, $6.52 \%$ falls from the high, $5.79 \%$ gunshot wounds, $5.34 \%$ assaults, $3.62 \%$ stab wounds, $2.89 \%$ others. Impressively, 16 patients $(5.89 \%)$ had no records of respiratory rate from the prehospital care assessment, $20(7.24 \%)$ had no data of systolic blood pressure and $13(4.71 \%)$ had no pulse registry. Furthermore, $31.25 \%$ of the RR not registered were abnormal in the hospital admission evaluation, as well as $15 \%$ of the SBPs, and $23 \%$ of HR. None of the cases had information regarding time from the scene to the hospital.

Conclusion: Electronic data collection shall make checklists consistently filled out. It is not well understood the importance of registering data for most of healthcare providers working in the field, especially when they do not follow the in-hospital care of trauma patients.

Keywords: Trauma registry, Prehospital trauma care, Prevention.

\footnotetext{
${ }^{1}$ Resident, ${ }^{2-4}$ Professor

${ }^{1}$ Department of Surgery and Orthopedics, State University of Sao Paulo, São Paulo, Brazil

${ }^{2-4}$ Department of Surgery, Federal University of Parana Parana, Brazil
}

Corresponding Author: Phillipe Abreu-Reis, Resident Department of Surgery and Orthopedics, State University of Sao Paulo, São Paulo, Brazil, Phone: 5514981354512, e-mail: phillipeareis@gmail.com
How to cite this article: Abreu-Reis P, Tomasich FS, Nasr A, Collaco I. Prehospital Trauma Care Registry Problems in South Brazil. Panam J Trauma Crit Care Emerg Surg 2014;3(3):97-100.

Source of support: Nil

Conflict of interest: None

\section{RESUMO}

Introdução: O registro de trauma continua a ser um grande problema para a maioria dos países que estão implementando sistemas de trauma. Coleta e armazenamento de dados de forma não digital pode levar a deterioração da informação ao longo do processo. A fim de verificar o que falta ser registrado na ficha de atendimento pré-hospitalar ao trauma, realizamos este estudo.

Métodos: Estudo não controlado prospectivo observacional com 288 casos aleatórios de trauma levados a um centro de trauma nível 1, em Curitiba, entre os dias 28 de maio e 10 de junho 2006. Foram analisados os dados registrados na ficha de atendimento pré-hospitalar do resgate. Os critérios de inclusão foram todos os pacientes trazidos ao o centro de trauma por ambulâncias. Os critérios de exclusão foram pacientes não transportados por ambulâncias e aqueles sem a ficha de atendimento apropriadamente preenchida. A análise estatística foi realizada usando o qui-quadrado para variáveis discretas, e teste t de Student para variáveis contínuas.

Resultados: Duzentos e oitenta e oito casos de trauma foram observados. Doze pacientes foram excluídos. Dos 276 pacientes que atenderam aos critérios de inclusão, $75 \%$ eram homens, com idade média de 27 anos. Em apenas 8,34\% das vezes os pacientes foram transportados por médicos, enquanto em $91,66 \%$ por socorristas. $63,4 \%$ dos pacientes foram vítimas de acidentes de trânsito, seguido por $12,31 \%$ de quedas da própria altura, $6,52 \%$ de quedas de nível superior, com $5,79 \%$ ferimentos por arma de fogo, 5,34\% agressões físicas, de $3,62 \%$ ferimentos por arma branca, $2,89 \%$ outros. 16 pacientes $(5,89 \%)$ não tinham registros de freqüência respiratória do atendimento pré-hospitalar, $20(7,24 \%)$ não tinham dados de pressão arterial sistólica e 13 (4,71\%) não tinham registro de frequência cardíaca. Além disso, 31,25\% não tiveram a frequência respiratória registrada e estavam anormais na admissão hospitalar, assim como $15 \%$ das aferições de pressão arterial, e $23 \%$ de frequência cardíaca. Nenhum dos casos tinha informações sobre o tempo de transporte para o hospital.

Conclusões: Coleta de dados de forma eletrônica poderá fazer com que checklists sejam consistentemente preenchidos. A importância do registro de dados não é reconhecida pela maioria dos profissionais de saúde, especialmente quando eles não seguem o atendimento intra-hospitalar de pacientes de trauma.

Palavras chave: Registro de Trauma, Atendimento préhospitalar, Prevenção, PHTLS. 


\section{INTRODUCTION}

Trauma is an important public health problem. It is currently the third leading cause of death in Brazil and worldwide, with the majority of deaths among the economically active population (20-30 years old).

Considering Brazilian data, there were 929,240 admissions to hospitals due to external causes and 141,227 deaths related to trauma. ${ }^{1}$ For the 5-year period 2005 to 2009, external causes are the third leading cause of death in Brazil (12.57\%), exceeded only by heart disease and cancer. ${ }^{2}$ This prevalence is also observed in the international literature, but mainly because of the aging process of population and the increasing incidence of cancer, those disease tend to overcome the external causes.

These data make clear the importance of preventing deaths related to external causes, especially regarding traffic accidents, which should be seen as a real problem of public health. ${ }^{3}$ In Brazil, south region accounts for the third place in hospital admissions ranking. In 2010, the state of Parana alone had more than 70,000 admissions, being $24.28 \%$ only in the city of Curitiba (capital city). The total number of deaths in the state was 9,491 people (1,440 at Curitiba). ${ }^{4}$

In addition to the quantifiable costs spent on trauma victims' treatment, there is an important economic burden that cannot be measured in terms of useful-years lost, because of the prevalence of death among young people. ${ }^{5}$

The distribution of deaths in trauma occurs in a trimodal pattern. Half of these deaths occur in the scene due to severe injuries incompatible with life. ${ }^{6}$ Thirty percent of deaths occur in the famous 'Golden Hour' between the prehospital care and the initial treatment in the emergency room. Other deaths usually occur during the in-hospital care.

The first peak can only be reduced through public health preventive actions. Investments in rescue and

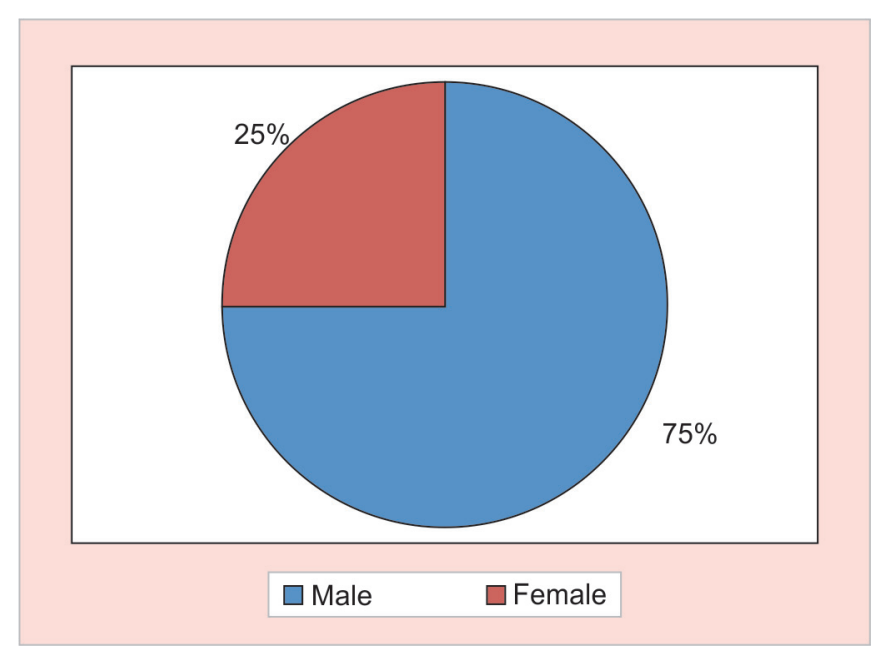

Graph 1: Sex distribution prehospital care interfere in the second time. Finally, the in-hospital treatment will only reduce deaths from the third peak of incidence.

The hospital do Trabalhador in the city of Curitiba, Brazil, is a well-established Level I Trauma Center. ${ }^{7}$ It has the only emergency department in the city that utilizes an 'open door system' (where the citizen can seek assistance directly) without referral by other hospitals or physicians. The emergency room of the hospital do Trabalhador admitted 63,057 patients in 2010 and performed approximately 1,500 surgeries per month. This public hospital is covered exclusively by the Brazilian Unified Health System (SUS). ${ }^{8}$

Trauma registry concept arose to identify the profile of trauma in urban areas, combining GIS data with interventionist actions in public health. In Brazil, these registry systems still appear to be at secondary level among trauma systems. ${ }^{9,10}$ Moreover, it is not difficult to notice the heterogeneity of healthcare services around the country.

Curitiba Graphs in this scenario as a model of capital city, with a great structure of health services, what makes the expectations of innovation to come from this city. ${ }^{11}$

Trauma Registry begins with the complete measurement of data at the trauma scene associated with the proper completion of standardized forms. It is noteworthy that in Brazil these data are not recorded electronically.

In the initial assessment of trauma patients is the fundamental to verify vital signs, since it is through this parameters that injury severity score is measured (all trauma indices derived RTS-Revised Trauma Score) which considers only the heart rate, respiratory rate, pressure systolic blood pressure and Glasgow coma Scale.

This study was conducted to assess the adequacy of the basic records of trauma in prehospital trauma at Curitiba and to identify missing data in the prehospital rescuers' form.

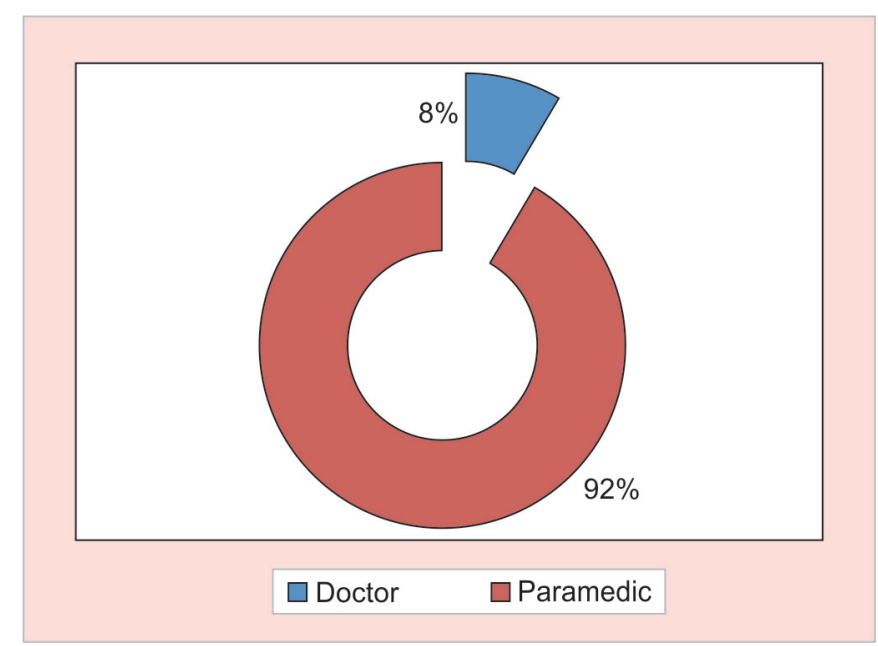

Graph 2: Healthcare provider responsible for PHTLS 


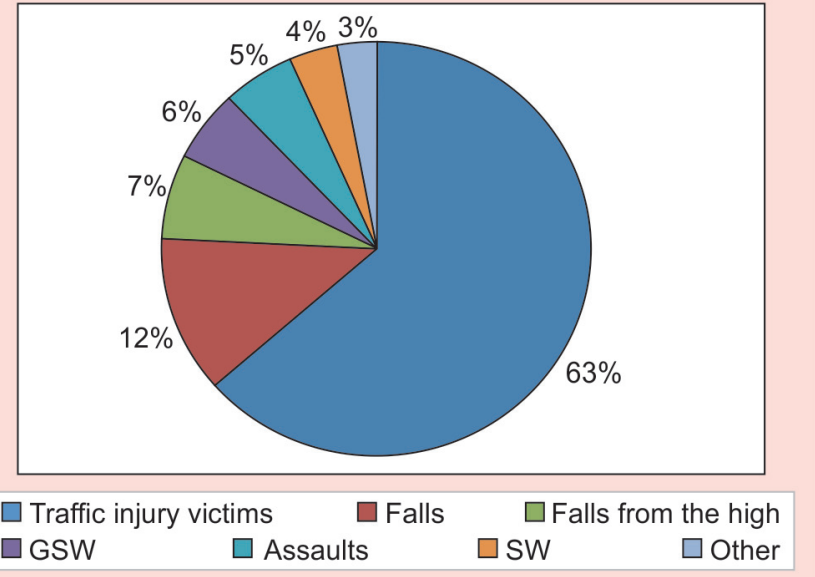

Graph 3: Mechanisms of injury

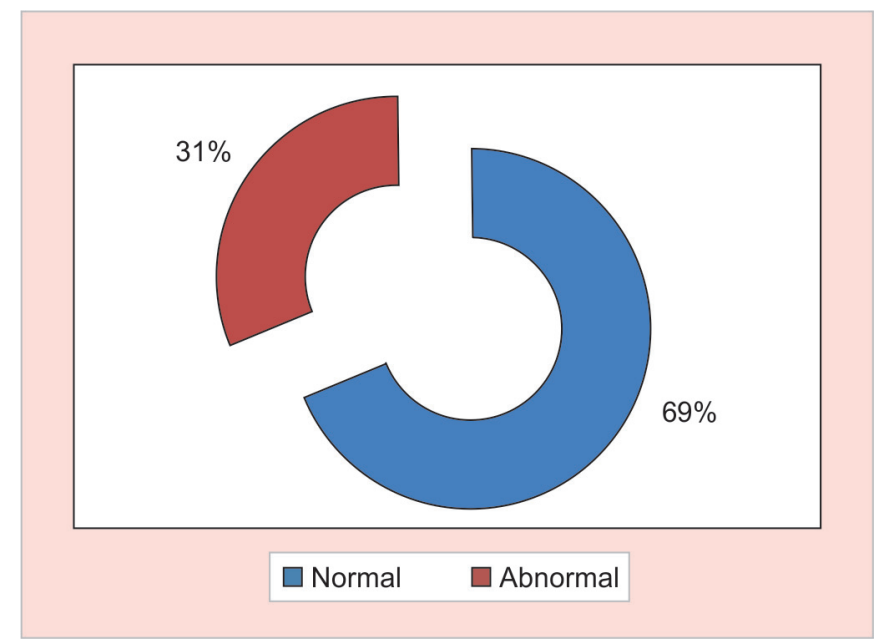

Graph 5: Respiratory rate analysis

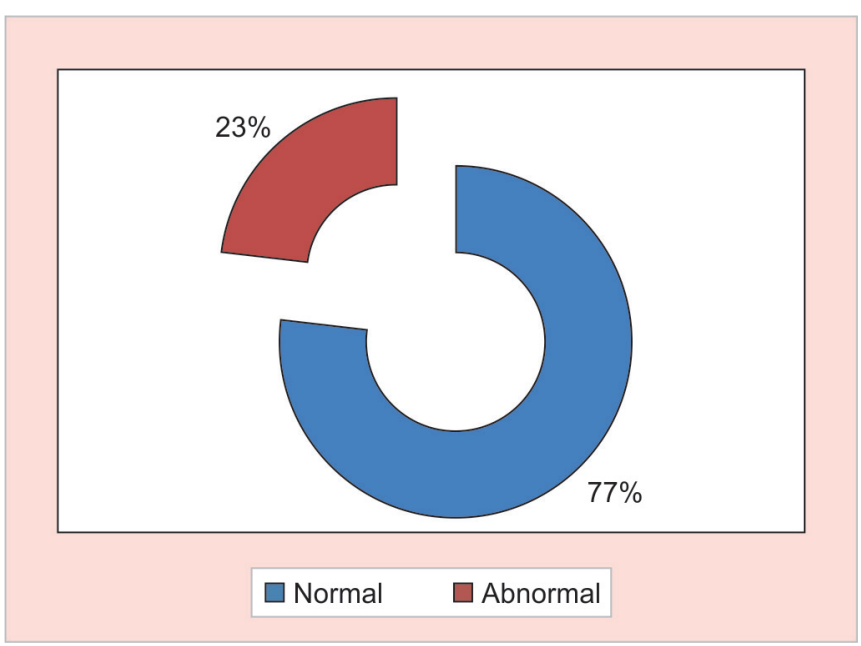

Graph 7: Heart rate assessment

\section{METHODS OF RESEARCH}

Observational retrospective uncontrolled study.

Data were collected from patients medical records completed by prehospital paramedics of SIATE and SAMU and compared with the data collected by the staff of the emergency room of Hospital do Trabalhador.

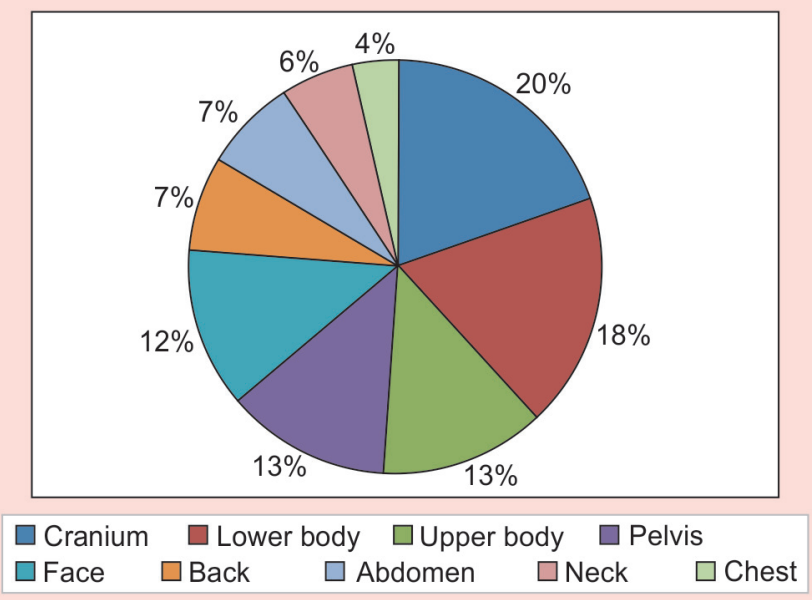

Graph 4: Injured body parts—by segment

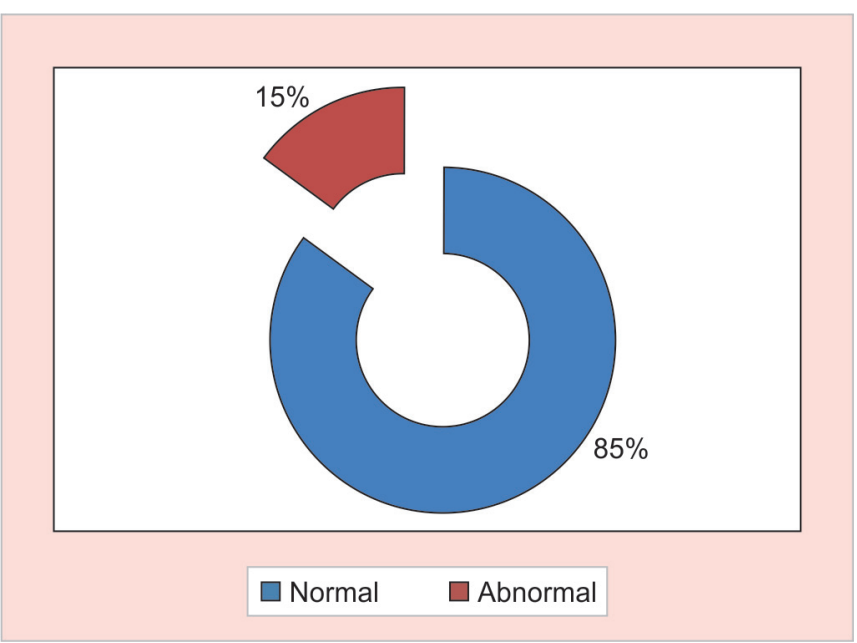

Graph 6: Systolic blood pressure evaluation

All patients delivered to the trauma center between May 28 and June 10 were considered for the study. The study period was determined randomly (according to the availability of the researchers who collected data).

We included all patients delivered to the trauma center during the study period, aged over 18 year-old.

Patients younger than 18 years, patients brought by ways other than ambulance, patients who were admitted to hospital for more than 24 hours and patients who died on arrival at hospital.

Statistical analysis was performed using the chi square for discrete, and the student's t-test for continuous variables.

\section{RESULTS}

Of the 288 patients brought to HT on the period, 12 were excluded. The average age was 27 years-old, with a prevalence in men (75\%) (Graph 1). PHTLS was carried out by a doctor only in $8 \%$ of cases, which probably represent the most severe trauma (Graph 2).

Regarding the mechanism of injury, there was a significant prevalence in traffic accidents, followed by falls 
from height and falls. Gunshot wound graphed in only $6 \%$ of visits (Graph 3).

The body segment attained in most cases was the skull, followed by the lower and upper limbs (20\%, $18 \%$ and $16 \%$ respectively) (Graph 4 ).

In 16 patients (5.89\%), there were no records regarding respiratory rare from PHTLS form. In 20 patients $(24.7 \%)$ there were missing records of systolic blood pressure. In 13 patients $(4.71 \%)$, the heart rate of patients was not recorded.

We assume that data not recorded were not verified, and thus it is an extremely serious situation, since that basic data in the evaluation of patients have not been searched by rescuers.

Evaluating missing data on admission to the trauma center, we observed that $31 \%$ of patients who had respiratory rate not verified at PHTLS showed tachypnea (Graph5). In addition, $15 \%$ of patients with no records of systolic blood pressure showed up hypotensive on admission, which may indicate hemorrhagic shock at least class III (Graph 6). Finally, in $23 \%$ of patients in which heart rate was not recorded there was tachycardia (Graph 7).

Moreover, no patient presented data from hemodynamic status on the scene of the trauma. Also, no patient had information regarding the transport time to the trauma hospital.

\section{DISCUSSION}

Our data show a public health problem underestimated by healthcare providers, since basic records regarding initial hemodynamic evaluation are not being recorded properly in routine medical charts.

Excess of work in hospitals sometimes explains the absence of many records in patient's chart, however in the prehospital environment the team is fully dedicated to a single patient.

The lack of continued training, as well as the ignorance about the importance of details may explain this terrible fail found in our study.

In spite of thinking that missing data could be related to less severe patients or to patients without hemodynamic instability, we observed a high number of patients with abnormal vital signs without any record of this condition in their prehospital care charts.

Considering effective systems of trauma, it is impossible to evaluate a system of which records of time from scene to the hospital are not registered.

Trauma registry should be planned and implemented in Brazilian cities, seeking to improve care and reduce trauma related mortality statistics in the first peak of the trimodal distribution of deaths.
Digital recording systems should be developed to minimize record miss-registering.

\section{CONCLUSION}

Electron date collection shell make checklists consistently filled out. The importance of registering data for most of healthcare provider working in the field especially when they do not follow the in-hospital care of trauma patients, needs to be emphasized.

\section{REFERENCES}

1. Laing GL, Bruce JL, Aldous C, Clarke DL. The design, construction and implementation of a computerised trauma registry in a developing South African metropolitan trauma service. Injury 2013 Jul 1.

2. Uemura N, Sugano K, Hiraishi H, Shimada K, Goto S, Uchiyama S, Okada Y, Origasa H, Ikeda Y. The MAGIC study group. Risk factor profiles, drug usage, and prevalence of aspirin-associated gastroduodenal injuries among high-risk cardiovascular Japanese patients: the results from the MAGIC study. J Gastroenterol 2014 May;49(5):814-824.

3. de Abreu RPGT, Camila N, Tabatha N, Adonis N, Saavedra TFD, Augusto CI. Guidelines for discharge: do standardized cards help in patient understanding? Rev Col Bras Cir 2013;40(4):335-341.

4. de Abreu RPGT, Luiza DA, da CACBA, Adonis N, Augusto CI, Saavedra TFD. Epidemiological profile of work-related accidents with biological exposure among medical students in a surgical emergency room. Rev Col Bras Cir 2013;40(4):287-292.

5. de Abreu RPGT, Arthur C, Giana S, Adonis N, Augusto CI, Saavedra TFD. Treatment of cutaneous traumatic wounds in the emergency room: what makes difference? J Bioanal Biomed 2013;5:130-132.

6. Marttos AC, Kuchkarian FM, Abreu-Reis P, Pereira BM, Collet-Silva FS, Fraga GP. Enhancing trauma education worldwide through telemedicine. World J Emerg Surg 2012 Aug 22;7(Suppl)1:S4.

7. Abreu-Reis P, Oliveira GC, de Oliveira AC, Sadique H, Nasr A, Saavedra Tomasich FD. Extra-curricular supervised training at an academic hospital: is 200 hours the threshold for medical students to perform well in an emergency room? World J Emerg Surg 2012 Aug 22;7 Suppl 1:S12.

8. Adonis N, Carolina T, Giana S, Iwan C, Micheli D, Phillipe AR. Prevencao ao trauma e atendimento de qualidade: uma decada de liga academica do trauma no hospital do trabalhador - UFPR (Curitiba-PR, Brasil). Pan J Trauma 2012 May-Aug;1(2):127-130.

9. Adonis N, Irene N, Valeria RA, Guilherme K, Phillipe AR. Radiologist vs surgeon: Misdiagnoses in radiologic evaluation by on-duty surgeons in the emergency room. Pan J Trauma 2012 Jan-Apr;1(1):38-43.

10. Marttos A, Kuchkarian FM, Palaios E, Rojas D, Abreu-Reis P, Schulman C. Surgical telepresence: the usability of a robotic communication platform. World J Emerg Surg 2012 Aug 22;7 (Suppl)1:S11.

11. Adonis N, Flavio T, Brunol P, Marilia M, Luisa O, Helena S, Juliana C, Iwan C, Phillipe AR. Preventive peer-educational activities: what can medical students do to potentially save lives? Pan J Trauma 2012 Sep-Dec;1(3):182-185. 